\title{
Változások az őssejt-transzplantációhoz társult thromboticus microangiopathia diagnosztikus kritériumrendszerében
}

\author{
Horváth Orsolya dr. ${ }^{1,3}$ - Prohászka Zoltán dr. ${ }^{2}$ - Kállay Krisztián dr. $^{3}$ \\ Kassa Csaba dr. ${ }^{3}$. Stréhn Anita dr. ${ }^{3}$ - Csordás Katalin dr. ${ }^{3}$ \\ Sinkó János dr. ${ }^{4}$ - Kriván Gergely dr. ${ }^{3}$ \\ Semmelweis Egyetem, ${ }^{1}$ Doktori Iskola, \\ ${ }^{2}$ Általános Orvostudományi Kar, III. Belgyógyászati Klinika, Budapest \\ Egyesített Szent István és Szent László Kórház, \\ ${ }^{3}$ Gyermekhematológiai és Őssejt-transzplantációs Osztály, \\ ${ }^{4}$ Hematológiai és Őssejt-transzplantációs Osztály, Budapest
}

\begin{abstract}
Az ôssejt-transzplantációhoz társult thromboticus microangiopathia egy multifaktoriális szövődmény transzplantáció után. Incidenciája a különböző diagnosztikus kritériumrendszerek miatt nagyon eltérő az irodalomban. A thromboticus microangiopathia aktivitását jelző klinikai paraméterek, így a laktátdehidrogenáz-emelkedés, a hematológiai paraméterek és a vesefunkció változásai az őssejt-transzplantáció után nem specifikusak. A patomechanizmusában a klasszikus és az alternatív út diszregulációjának egyaránt szerepe lehet, azonban a komplex patomechanizmus pontosan még nem ismert. A jövőben a komplement paraméterek, köztük a terminális komplement út aktivációs komplex monitorozása segítheti a klinikusokat a gyors és pontos diagnózisban, a kezelésre szoruló betegek optimális kiválasztásában, a terápia várható hatékonyságának előrejelzésében és eredményességének monitorizálásában. A közlemény a thromboticus microangiopathia diagnosztikus kritériumrendszereinek és a terápiás lehetőségeinek változásait, valamint a hazai gyermek betegekben szerzett tapasztalatokat mutatja be.
\end{abstract}

Orv Hetil. 2017; 158(27): 1043-1050.

Kulcsszavak: vérképző őssejt-transzplantáció, thromboticus microangiopathia, komplementaktiváció

\section{Changes in diagnostic criteria of thrombotic microangiopathy after stem cell transplantation}

Hematopoietic stem cell transplantation associated thrombotic microangiopathy is a multifactorial complication, and has variable incidence in study populations due to different diagnostic criteria. The diversity of activity parameters, like elevated laktát-dehidrogenáz, hematological parameters and kidney function are not specific variables after stem cell transplantation. Dysregulation of the classical and alternative pathway can play an important role in the pathomechanism of thrombotic microangiopathy, but the understanding of the role of complement activation under transplantation conditions requires further investigation. Monitoring of complement parameters, including terminal complement pathway activation complex during transplantation may help physicians to improve diagnostic strategy, to evaluate therapeutical options and to predict and follow up efficacy of complement blockade methods and supportive therapy. This review focuses on the development of diagnostic criteria and therapeutical options in thrombotic microangiopathy, and presents some preliminary findings while using different diagnostic criteria in pediatric patients.

Keywords: hematopoietic stem cell transplantation, thrombotic microangiopathies, complement activation

Horváth O, Prohászka Z, Kállay K, Kassa Cs, Stréhn A, Csordás K, Sinkó J, Kriván G. [Changes in diagnostic criteria of thrombotic microangiopathy after stem cell transplantation]. Orv Hetil. 2017; 158(27): 1043-1050.

(Beérkezett: 2017. április 14.; elfogadva: 2017. május 15.) 


\section{Rövidítések}

ADAMTS13 = von Willebrand-faktort hasító proteáz; ASBMT = (American Society of Blood and Marrow Transplantation $)$ Amerikai Csontvelő-transzplantációs Társaság; GVHD = graft versus host betegség; HUS = haemolyticus uraemiás szindróma; IWG = (International Working Group) Nemzetközi Munkacsoport; LDH = laktátdehidrogenáz; $\mathrm{MOF}=$ (multiple organ failure) sokszervi elégtelenség; O-TMA $=$ (overall thrombotic microangiopathy grouping) összesített thromboticus microangiopathia csoportosítás; sC5b-9 = szolúbilis terminális út aktivációs komplex; TA-TMA = őssejt-transzplantációhoz társult thromboticus microangiopathia; TMA = thromboticus microangiopathia; TTP $=$ thromboticus thrombocytopeniás purpura

\section{A thromboticus microangiopathiák}

A thromboticus microangiopathia jellegzetes szövettani eltérések együttese, többféle klinikai szindróma is megjelenhet ezzel a képpel. Közös jellemző az endothelialis károsodás, a microvascularis thrombusképződés, azonban az elváltozások lokalizációja, kiterjedtsége és ennek megfelelően a klinikai kép lényegesen eltér [1]. A thromboticus thrombocytopeniás purpura (TTP) és a hae- molyticus uraemiás szindróma (HUS) egyaránt a TMA-k közé sorolhatóak [2]. A thromboticus microangiopathiák részletes felosztását az 1 ábra mutatja be [3].

A TMA-k közül a TTP az elsőként leírt klinikai entitás, az első esetet Moschcowitz közölte 1925-ben [4]. A TTP jellegzetes klinikai pentádja a consumptiós thrombocytopenia, a fragmentocytás haemolyticus anaemia, a fluktuáló idegrendszeri tünetek, a veseérintettség és a láz. A pentád a TTP-s esetek 40\%-ában, az első három tünet 70-80\%-ban mutatható ki. A TTP diagnózisa kimondható a más okkal nem magyarázható thrombocytopenia és a fragmentocytás haemolyticus anaemia igazolása esetén $[5,6]$. A HUS jellemző klinikai triádja a consumptiós thrombocytopenia, a microangiopathiás haemolyticus anaemia és az igazolt akut vesekárosodás (proteinuria, glomerularis haematuria, beszúkült vesefunkció, oligo-anuria, emelkedett retenciós értékek) [7]. Gyermekkorban a leggyakoribb a hasmenést követő HUS, amelyért a Shiga toxintermelö E. coli törzsek által okozott infekciók felelősek $[6,8]$. A TTP és a HUS primer okainak differenciáldiagnosztikájára már részletes, a komplementdiagnosztikára és a genetikai vizsgálatokra is épülő kritériumrendszereket dolgoztak ki [9, 10].

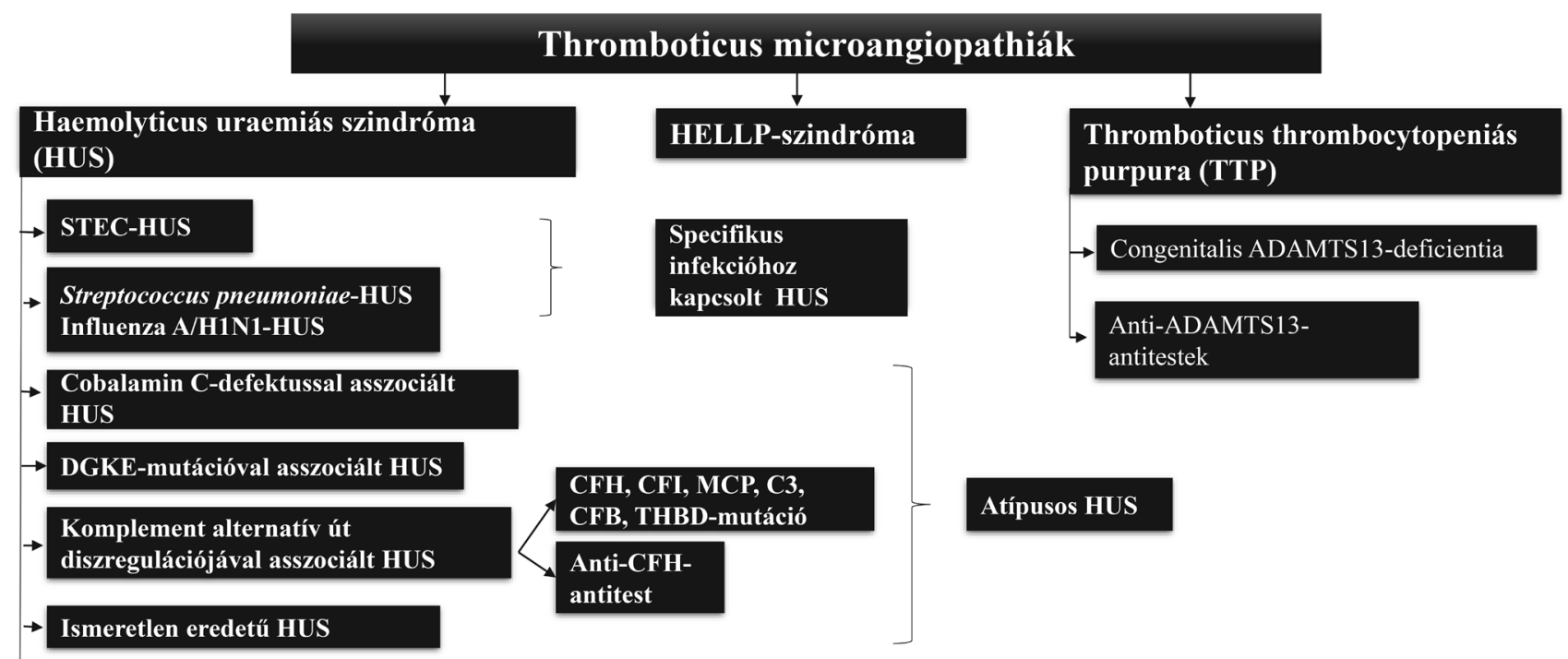

Szekunder HUS/TTP alapbetegség mellett

- Gyógyszerek

- Neoplasia/aktív kemoterápia

- Csontvelö-transzplantáció

- Egyéb szolid szervátültetés

- Autoimmun betegségek

- Infekciók

- Malignus hypertensio

- Mütétek, fehérjevesztő állapotok, pancreatitis

1. ábra A thromboticus microangiopathiák felosztása [3]

ADAMTS13 = von Willebrand-faktort hasító proteáz; CFB = komplement faktor B; CFH = komplement faktor $\mathrm{H}$; CFI = komplement faktor I; DGKE = diacil-glicerol-kináz $\varepsilon ;$ HELLP = haemolysis, emelkedett májenzimek, alacsony thrombocytaszám szindróma; MCP = membránkofaktorprotein $(\mathrm{CD} 46) ; \mathrm{STEC}=$ Shiga toxint termelő Escherichia coli THBD = thrombomodulin) 


\begin{tabular}{|c|c|c|c|c|c|}
\hline Paraméter & ASBMT & IWG & Cho és mtsai & City of Hope & Jodele és mtsai \\
\hline $\mathrm{LDH}$ & $\begin{array}{l}\text { A normálérték felső } \\
\text { határa felett }\end{array}$ & $\begin{array}{l}\text { A normálérték } \\
\text { felső határa felett }\end{array}$ & $\begin{array}{l}\text { A normálérték } \\
\text { felső határa felett }\end{array}$ & $\begin{array}{l}>2 \times \text { a normálérték } \\
\text { felső határa felett }\end{array}$ & $\begin{array}{l}\text { Az életkornak megfelelő } \\
\text { felső normális határérték } \\
\text { felett }\end{array}$ \\
\hline Thrombocytopenia & Nem & $\begin{array}{l}<50 \times 10 \_9 / \mathrm{L} \\
\text { vagy legalább } \\
50 \% \text {-os csökkenés } \\
\text { a korábbi értékhez } \\
\text { képest }\end{array}$ & $\begin{array}{l}<50 \times 10 \_9 / \mathrm{L} \\
\text { vagy legalább } \\
50 \% \text {-os csökkenés a } \\
\text { korábbi értékhez } \\
\text { képest }\end{array}$ & $\begin{array}{l}<50 \times 10 \_9 \mathrm{G} / \mathrm{L} \\
\text { vagy }>50 \% \\
\text { csökkenés }\end{array}$ & $\begin{array}{l}<50 \times 10 \_9 / \text { L vagy } \\
\text { legalább } 50 \% \text {-os } \\
\text { csökkenés a korábbi } \\
\text { értékhez képest }\end{array}$ \\
\hline Anaemia & Nem & $\begin{array}{l}\text { Csökkent } \\
\text { hemoglobin vagy } \\
\text { növekvő } \\
\text { transzfúziós igény }\end{array}$ & $\begin{array}{l}\text { Hemoglobin } \\
\text { csökkenése }\end{array}$ & Nem & $\begin{array}{l}\text { Hemoglobinszint az } \\
\text { életkori normálérték } \\
\text { alsó határa alatt vagy } \\
\text { transzfúziót igénylő } \\
\text { anaemia }\end{array}$ \\
\hline Schistocyta & $>2$ látóterenként & $>4 \%$ & >2 látóterenként & $\begin{array}{l}\text { Schistocyták } \\
\text { jelenléte és } \\
\text { perzisztáló magvas } \\
\text { vörösvérsejtek }\end{array}$ & $\begin{array}{l}\text { >2 látóterenként vagy } \\
\text { schistocyták jelenléte } \\
\text { a szövettani mintában }\end{array}$ \\
\hline Haptoglobin & Nem & Csökkent & Csökkent & Nem & Nem \\
\hline Vesefunkció & $\begin{array}{l}\text { Szérumkreatinin } \\
\text { a kiindulási érték } \\
\text { kétszerese (vagy } \\
\text { neurológiai diszfunkció) }\end{array}$ & Nem & Nem & $\begin{array}{l}\text { Szérumkreatinin a } \\
\text { kiindulási érték } \\
1,5 \text {-szerese }\end{array}$ & $\begin{array}{l}\text { Proteinuria } \\
\text { (random }>30 \mathrm{mg} / \mathrm{dl} \text {; } \\
\text { magas rizikójú } \\
\text { TMA-kritérium) }\end{array}$ \\
\hline Negatív Coombs-teszt & Igen & Nem & Igen & Nem & Nem \\
\hline Magas vérnyomás & Nem & Nem & Nem & Nem & Igen (percentilis) \\
\hline $\begin{array}{l}\text { Terminális komplement } \\
\text { komplex }\end{array}$ & Nem & Nem & Nem & Nem & $\begin{array}{l}\text { Emelkedett sC5b-9 } \\
\text { (magas rizikójú } \\
\text { TMA-kritérium) }\end{array}$ \\
\hline
\end{tabular}

ASBMT = Amerikai Csontvelő-transzplantációs Társaság; IWG = Nemzetközi Munkacsoport; LDH = laktátdehidrogenáz; sC5b-9 = szolúbilis terminális komplement komplex

\section{Az őssejt-transzplantációhoz társult thromboticus microangiopathia}

A transzplantációhoz társult thromboticus microangiopathia a TMA-kon belül önálló entitás. Etiológiája multifaktoriális, a pontos patomechanizmusa még nem ismert, ezért a szekunder TMA-k közé sorolható [11]. Kiváltó okaként az immunszuppresszív szereknek, a kondicionáló kezelés okozta toxicitásnak, a teljestest-besugárzásnak, a vírusfertőzéseknek és a graft versus host betegségnek (GVHD) egyaránt szerepe lehet [12]. Hátterében generalizált endotheldiszfunkció áll, amely egyes esetekben sokszervi károsodáshoz, ezáltal gyorsan progrediáló sokszervi elégtelenséghez vezet [2]. Incidenciáját az őssejt-transzplantáció során alkalmazott kondicionáló kezelés, a többi őssejt-transzplantációs szövődmény jelentkezése és a recipiens komplementrendszer fehérjéinek génvariánsai befolyásolják [13, 14].

Bár a TA-TMA klinikai megjelenése és gyakorisága miatt egy jelentős és súlyos szövődmény, pontos definiálása és az egységes kritériumrendszer megalkotása az elmúlt évtizedben került a tudományos érdeklődés középpontjába [9].

\section{A diagnosztikus kritériumrendszerek változása őssejt-transzplantációhoz társult thromboticus microangiopathiában}

A multifaktoriális patomechanizmus és az egységes elfogadott kritériumrendszer hiánya miatt a TA-TMA incidenciája nagyon különböző $(0,5 \%-63,6 \%)$ az egyes közleményekben $[15,16]$. Az őssejt-transzplantációhoz társult TMA-ra kidolgozott kritériumrendszerek a többi TMA-formához hasonlóan a hematológiai aktivitás és a szervkárosodás jeleit veszik alapul [15, 17-20]. Az anaemia és thrombocytopenia értékelésénél figyelembe vették a transzplantált betegek hematológiai sajátosságait, és a beteg korábbi értékeihez és addigi transzfúziós igényéhez viszonyítják a hematológiai paraméterek romlását. A definíció alkalmazását nehezíti, hogy a különböző intézményekben és a különböző állapotú betegek esetén azonban más lehet a transzfúzió indikációja. A TA-TMA iránti intenzív szakmai érdeklődést jól mutatja, hogy az elmúlt évtizedben öt különböző kritériumrendszer is született a TA-TMA definiálására, melyeket az 1. táblázat mutat be [14, 16-19]. 
Elsőként az Amerikai Csontvelő-transzplantációs Társaság munkacsoportja (Blood and Marrow Transplants Clinical Trials Network - ASBMT-munkacsoport) fogalmazott meg egységes kritériumokat 2005-ben [17]. Definíciójuk alapján a hematológiai paraméterek romlása nem szükséges a TA-TMA kimondásához, amelyet a thrombocytopenia nagy gyakoriságával indokoltak a korai transzplantáció utáni időszakban. A TA-TMA súlyosságának meghatározásához a szérumkreatinin-érték emelkedésével jellemzett vesefunkció-romlást vették alapul, és ez az egyetlen kritériumrendszer, amelyben kritériumként - a TTP-hez hasonlóan - alternatívaként a neurológiai diszfunkció is szerepel [17].

Ezzel szemben a Nemzetközi Munkacsoport (International Working Group - IWG) definíciója a hematológiai paraméterek változása közül figyelembe veszi mind a vérlemezkeszám csökkenését, mind az anaemiát és a csökkent haptoglobint, azonban a vesefunkció romlása nem szükséges a TA-TMA kimondásához. A definíció megfogalmazása elméleti alapon történt, és nem validálták prospektív klinikai vizsgálat keretében [18].

Cho és mtsai 2010-ben az első két közlemény összegzése és egy nagy esetszámú, multicentrikus, őssejttranszplantáción átesett felnőtt betegek körében végzett retrospektív vizsgálat során a két rendszer összegzését és egy új definíció megfogalmazását tűzték ki célul. Az O-TMA-csoportosítás (overall thrombotic microangiopathy grouping - összesített thromboticus microangiopathia csoportosítás) a koagulációs paraméterek ellenőrzését is ajánlja a disszeminált intravascularis koaguláció kizárására [15]. Bár az O-TMA az ASBMT-kritériumokkal ellentétben nem veszi figyelembe a romló vesefunkciót, Cho és mtsai retrospektív, felnőtt betegek körében végzett vizsgálatukban a 86 TA-TMA-ként definiált betegüknél 83 betegnél csökkent vesefunkciót is találtak [15]. A TA-TMA-ra a negyedik közlemény 2015-ben született a City of Hope transzplantációs centrumban, ennek során egy prospektív kohorszvizsgálatban saját TA-TMA diagnosztikus kritériumokat fogalmaztak meg [19].

A 2000-es évek végén, az atípusos HUS és a TTP etiológiájának tisztázásában a komplementdiagnosztika, valamint az ADAMTS13 (von Willebrand-faktort hasító proteáz) enzimaktivitás és inhibitor meghatározása alapvető vizsgálóeljárássá vált $[5,21]$. Ugyanakkor, az őssejttranszplantációhoz társult TMA diagnosztikájára kialakított, fent bemutatott négy kritériumrendszer csak a klinikai paramétereken alapult. Ennek nagyrészt az volt az oka, hogy a TA-TMA patomechanizmusa sokáig ismeretlen volt. A komplementrendszer aktivitását őssejttranszplantáció után elsőként Jodele és mtsai vizsgálták részletesen. Eredményeik alapján a TA-TMA patomechanizmusában mind a klasszikus, mind az alternatív út diszregulációjának szerepe lehet [22]. Első közleményeikben az O-TMA-kritériumrendszert használták a szövődmény definiálására [20,22]. Prospektív vizsgálatukra alapozva 2015-ben a korábbi kritériumok átértékelésével új TA-TMA-definíciót fogalmaztak meg. Elsőként ajánlották TA-TMA-ban a klinikai diagnózis időpontjában az ADAMTS13 és a komplementrendszer aktivitását jelző paraméterek vizsgálatát. A komplement paraméterek közül az emelkedett terminális út aktivációs komplex (sC5b-9) szint mérését javasolták. A normálérték feletti sC5b-9-szinttel (>250 ng/ml) rendelkező TA-TMA-s betegeket magas rizikójú TMA-nak tekintették [2, 20].

Az öt kritériumrendszer összegzésével megállapíthatjuk, hogy bár minden rendszer ugyanannak a transzplantációs szövődménynek a definiálására szolgál, és az emelkedett LDH-t minden definíció figyelembe veszi, a vesefunkció és a hematológiai paraméterek eltérő értékelése miatt azonban jelentős különbségek lehetnek abban, hogy végül melyik betegnél kerül megállapításra a transzplantációhoz társult thromboticus microangiopathia. Bár a TA-TMA korszerú diagnosztikája során az etiológia tisztázásához és a megfelelő kezelés gyors megkezdéséhez elengedhetetlen lehet a gyors komplementdiagnosztika, transzplantáció után csak Jodele és mtsai tesznek erre vonatkozó ajánlásokat közleményeikben [2]. Felnőtt betegekben a TA-TMA incidenciájára vonatkozóan több közlemény is született $[11,17]$, azonban gyermek betegekben csak kis esetszámú tanulmányok állnak rendelkezésünkre, amelyek nem tekintik át szisztematikusan a különböző kritériumokból adódó eltéréseket [2].

\section{Tapasztalataink a saját betegcsoportunkban}

A TA-TMA színes klinikuma és az egységes kritériumok hiánya miatt illusztrációként saját, allogén őssejt-transzplantáción átesett betegeinkkel szerzett tapasztalatainkat szeretnénk röviden bemutatni.

Harminchárom, őssejt-transzplantáción átesett gyermeket $(9,6 \pm 4,4$ év $)$ vizsgáltunk, akiknek 2013 novembere és 2015 júniusa között történt allogén vérképző őssejt-transzplantációja malignus $(\mathrm{n}=16)$ és nem malignus betegség $(\mathrm{n}=17)$ miatt az Egyesített Szent István és Szent László Kórház Gyermekhematológiai és Össejttranszplantációs Osztályán. Négy különböző TA-TMA diagnosztikus kritériumrendszer alapján soroltuk be a betegeinket: 1. az Amerikai Csontvelő-transzplantációs Társaság [17], 2 . az O-TMA-csoportosítás [15], 3. a City of Hope diagnosztikus kritériumai [19] és 4. Jodele és $m$ tsai diagnosztikus kritériumai alapján [20]. A Nemzetközi Munkacsoport definíciója alapján [18] ugyanazok a betegek kerültek a TA-TMA-betegcsoportba, mint az O-TMA-kritériumok alapján, ezért ezt a közlemény külön nem elemzi. Monitoroztuk a TA-TMA aktivitását jelző paraméterek változásait (thrombocytopenia, anaemia, LDH, haptoglobin, fragmentocyták, magas vérnyomás, proteinuria), és a transzplantáció előre meghatározott időpontjaiban meghatároztuk a komplement paramétereket (mindhárom komplement út aktivitása, ADAMTS13, terminális komplement út aktivációs komplex [sC5b-9]). 
1) T A-T M A az A SBM T kritériumok alapján

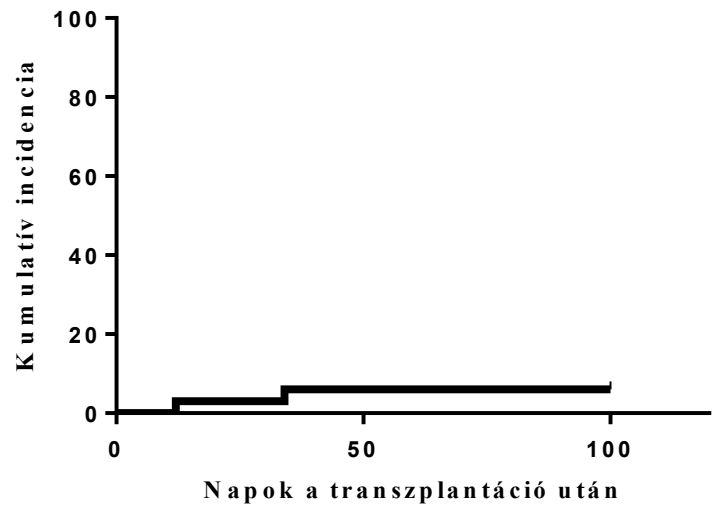

3) T A-T M A a City of Hope kritériumok alapján

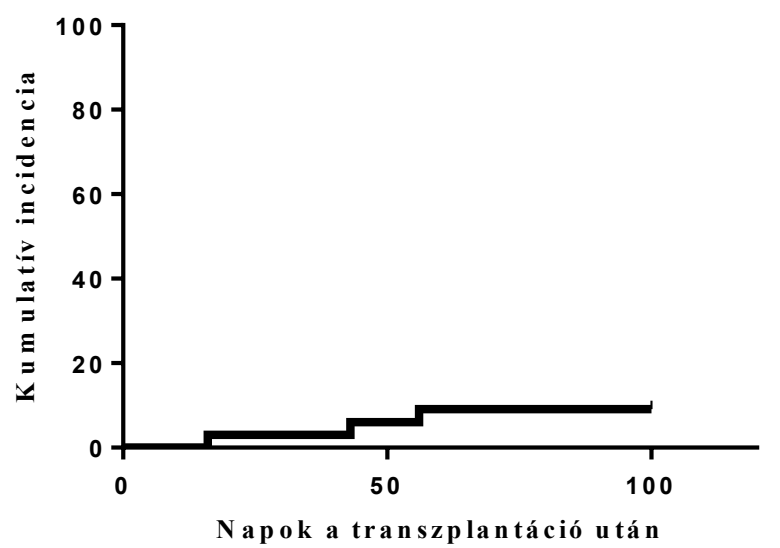

2) T A-T M A C Cho-féle kritériumok alapján

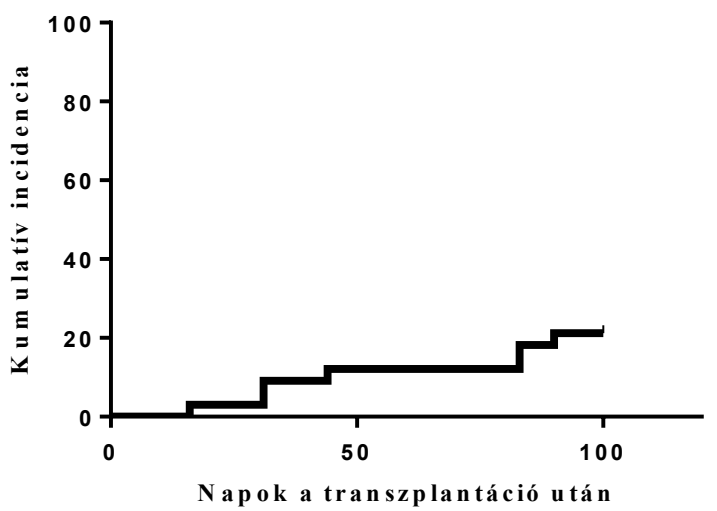

4) T A-T M A a Jodele-féle kritériumok alapján

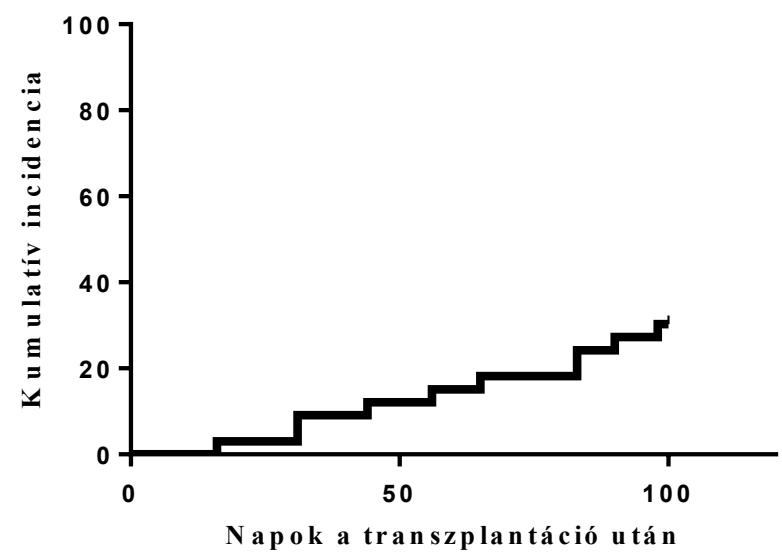

2. ábra

Thromboticus microangiopathia kumulatív incidenciája a diagnosztikus kritériumrendszerek alapján saját betegcsoportunkban ASBMT = Amerikai Csontvelö-transzplantációs Társaság; TA-TMA = transzplantációhoz társult thromboticus microangiopathia); $\mathrm{x}$ tengely = napok a transzplantáció után; y tengely = a TA-TMA kumulatív incidenciája a kritériumrendszerek alapján

Az Amerikai Csontvelő-transzplantációs Társaság (1.) diagnosztikus kritériumai szerint 2/33, az O-TMA-csoportosítás (2.) alapján $7 / 33$, a City of Hope diagnosztikus kritériumai (3.) alapján 3/33 és Jodele és mtsai kritériumai (4.) alapján 10/33 betegnél lépett fel TA-TMA. A betegek a diagnosztikus kritériumokat a transzplantáció utáni 12. és 34. napon teljesítették az 1., a medián 44 . (16-90) napon a 2., a 16., a 43. és az 56. napokon a 3. és a medián 61. (16-90) napon a 4. kritériumrendszer alapján. A TA-TMA kumulatív incidenciáját az 2. ábra mutatja be a négy diagnosztikus kritériumrendszer alapján.

Mind a nyolc betegnél, akik az első három diagnosztikus kritériumrendszer alapján TA-TMA-betegcsoportba kerültek, Jodele és mtsai definíciója alapján is kimondható volt a TA-TMA. A kezdeti szérumkreatinin-szint két beteg esetében duplázódott meg, akik mind a négy kritériumrendszer alapján TA-TMA betegcsoportba tartoznak. Minden TA-TMA betegcsoportba tartozó betegnél emelkedett sC5b-9- (>250 ng/ml) szintet mértünk a transzplantáció utáni 28 . $(\mathrm{n}=9 / 10)$ vagy $56 .(\mathrm{n}=8 / 9)$ napon.

Jodele és mtsai diagnosztikus kritériumrendszere alapján betegcsoportunkban 39\% a TA-TMA előfordulása az őssejt-transzplantált gyermekekben medián 2,03 (0,14$3,26)$ év követési idő alatt, és minden beteg a transzplantáció utáni első 100 napon belül teljesítette a TA-TMA diagnosztikus kritériumait, ami megfelel az eredetileg leírt incidenciának [20]. Az emelkedett sC5b-9-szintek miatt minden TA-TMA-s betegünk egyben magas rizikójú TMA-s betegnek tekinthető. Megjegyzendő, hogy betegeinknél az európai protokollok alapján eltérő, csökkentett toxicitású kondicionáló kezelést alkalmaztunk, amely befolyásolhatja a transzplantációs szövődmények jelentkezését. A szérumkreatinin-szint emelkedését is magába foglaló City of Hope-kritériumrendszerrel saját betegcsoportunkban 17\% volt a TMA incidenciája, amely szintén összevethető a 3/33 aránnyal betegcsoportunkban [19]. A többi kritériumrendszerrel idősebb, komorbid betegcsoport adatait közölték [23], amivel eredményeinket nehéz összehasonlítani.

A TA-TMA aktivitását jelzó paramétereket részletesen a 2. táblázat mutatja be, ahol a különböző TMA-aktivitási paraméterek teljesülése a transzplantáció utáni napok alapján látható. 
A thromboticus microangiopathia aktivitását jelző paraméterek teljesülése gyermek betegcsoportunkban a transzplantáció után időszakban a diagnosztikus TMA-kritériumok alapján (Kiemelve a bármelyik kritériumrendszer alapján TMA-s betegek; a számok azt a poszttranszplantációs napot jelentik, amikor az aktivitást jelző paraméterek teljesülnek)

\begin{tabular}{|c|c|c|c|c|c|c|c|c|c|}
\hline 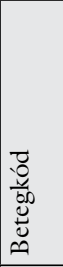 & 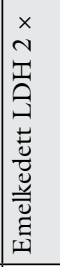 & 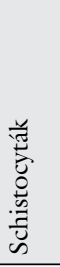 & 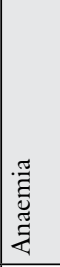 & 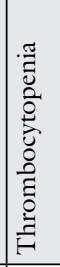 & 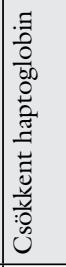 & 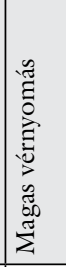 & 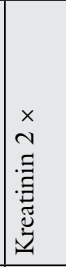 & 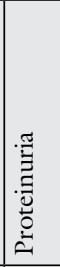 & 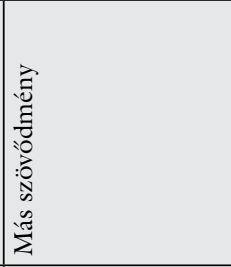 \\
\hline 1 & 47 & & & & 28 & & & & Relapsus \\
\hline 2 & 20 & & 47 & & & & & & GVHD \\
\hline 3 & & 12 & & & & & & & \\
\hline 4 & & 16 & & & 28 & & & & \\
\hline 5 & 12 & 5 & 14 & 16 & 14 & 5 & 7 & & GVHD \\
\hline 6 & & & & & & & 21 & & EBV, adeno \\
\hline 7 & 68 & 33 & 83 & 77 & 100 & 29 & & & GVHD \\
\hline 8 & 21 & & & 66 & 56 & & 33 & & CMV, relapsus \\
\hline 9 & & & & & 56 & & & & Relapsus \\
\hline 10 & 34 & 37 & & & & & & & \\
\hline 11 & 25 & 4 & 27 & 31 & 28 & 26 & & & CMV, EBV, PTLD \\
\hline 12 & 23 & 20 & & & & & & & \\
\hline 13 & 25 & 28 & 98 & 98 & & 67 & & & GVHD, adeno \\
\hline 14 & & & & & 56 & & & & \\
\hline 15 & 43 & 58 & 65 & 65 & & 60 & & 59 & GVHD, EBV \\
\hline 16 & 33 & 47 & & & & & 40 & & GVHD \\
\hline 17 & 18 & 32 & 56 & 53 & & -4 & & 32 & $\begin{array}{l}\text { GVHD, CMV, } \\
\text { adeno, rejekció }\end{array}$ \\
\hline 18 & 7 & 31 & 27 & 31 & 28 & 14 & & & GVHD \\
\hline 19 & & & & & & & & & CMV, relapsus \\
\hline 20 & 39 & & & & & & & & CMV \\
\hline 21 & 26 & 26 & 44 & 43 & 40 & 40 & 34 & 26 & $\begin{array}{l}\text { EBV, adeno, } \\
\text { PTLD, MOF } \\
\end{array}$ \\
\hline 22 & 102 & 63 & 86 & & & 27 & & 32 & CMV, relapsus \\
\hline 23 & & 24 & & & & & & 24 & GVHD, CMV \\
\hline 24 & 40 & 36 & & & & & & & $\begin{array}{l}\text { EBV, PTLD, } \\
\text { relapsus }\end{array}$ \\
\hline 25 & 34 & & & & & & 27 & & CMV \\
\hline 26 & & 46 & & 78 & 56 & & & & CMV \\
\hline 27 & 48 & 27 & 90 & 90 & 28 & 48 & & & $\begin{array}{l}\text { GVHD, CMV, } \\
\text { relapsus }\end{array}$ \\
\hline 28 & & & & & & & & & \\
\hline 29 & & & & & & 65 & & & GVHD, CMV \\
\hline 30 & 30 & & & & & & & & CMV \\
\hline 31 & 54 & & & & 28 & & & & \\
\hline 32 & 29 & 15 & & & 28 & & & & \\
\hline 33 & 48 & 72 & 72 & 83 & 28 & 60 & & 73 & Relapsus \\
\hline
\end{tabular}

$\mathrm{CMV}=$ cytomegalovirus; EBV = Epstein-Barr-vírus; GVHD = graft versus host betegség; kreatinin $2 \times=$ a transzplantáció előtti szérumkreatinin-szint megduplázódása; $\mathrm{LDH}=$ laktátdehidrogenáz (> az életkori felső határérték kétszerese); $\mathrm{MOF}=$ sokszervi elégtelenség; PTLD = poszttranszplantációs lymphoproliferativ betegség

\section{Szövettani diagnózis lehetősége}

A TA-TMA diagnózisának betegágy melletti megállapítását megnehezíti, hogy a TMA aktivitását jelző paraméterek változásai az őssejt-transzplantáció során nem specifikusak. Számos transzplantációs szövődmény okozhat változásokat az LDH-koncentrációban és a hematológiai paraméterekben, mint a vírusreaktivációk, a graft versus host betegség, vércsoport-inkompatibilitás, a venoocclusiv betegség, az antitestmediált thrombocytopenia és az alapbetegség relapsusa $[11,12,24]$. Allogén őssejtátültetés után az akut vesekárosodás ismert rizikófaktorai - a TMA-n kívül - a ciklosporin okozta toxicitás, a vírusreaktivációk kezelésére használt foscarnet és cidofovir, valamint az antimikotikum amphotericin B vesekárosító hatása $[25,26]$.

A TA-TMA szervérintettsége miatt nemcsak a diagnosztikus kritériumok segíthetnék a TMA felismerését, hanem a biopsziával nyert minták szövettani elemzése is. Az immunhiányos, thrombocytopeniás betegeknél nagy nehézséget jelent a biopszia kivitelezése. Az őssejttranszplantációt követő súlyos hasmenés komoly szövődmény, amelynek egyik fő oka a bélérintettséggel járó graft versus host betegség [27]. Az intestinalis TMA sokszor együtt jelentkezik a GVHD-val, amelynek egyik oka, hogy a GVHD terápiájaként adott immunszuppresszió triggerelheti az endothelkárosodást [27]. A szövettani elkülönítést megnehezíti, hogy a graft versus host betegség és a thromboticus microangiopathia által okozott bélelváltozások jelei nem specifikusak. TMA jelenlétére a szövetekben is látható fragmentocyták hívhatják fel a figyelmet [28]. A vesebiopszia szövettani eredményével őssejttranszplantált betegek esetén még nem áll rendelkezésre kellő számú tapasztalat.

\section{A terápiás gyakorlat változása transzplantációhoz társult microangiopathiában}

Az őssejt-transzplantációhoz társult TMA elsődleges kezelését a potenciális kiváltó faktorok felfüggesztése, eliminálása vagy kontrollálása jelenti [29]. TA-TMA jelentkezése esetén a kalcineurininhibitorok felfüggesztése az elsődleges lépés, amellyel az esetek egy részében a szövődmény stabilizálását vagy visszafordulását lehet elérni [2]. Míg az ADAMTS13 elleni antitestekkel járó TTP jól kezelhető plazmaferézissel, az ADAMTS13-inhibitor eltávolítása és a hiányzó enzim pótlása miatt a TA-TMA terápiájában a plazmaferézis nem első vonalbeli kezelési eljárás, mert kialakulásában az antitestek nem játszanak jelentős szerepet [22]. A TA-TMA hátterének részletesebb megismerése magyarázatot adott arra a klinikai megfigyelésre, hogy plazmaferézissel jelentős terápiás válasz TA-TMA-ban nem érhető el [30].

TA-TMA-ban a komplement terminális út aktivációja jön létre és emelkedett terminális komplementkomplexszint mérhető a betegek plazmájában [20]. Az eculizu- 
mab a C5 komplement komponenst gátló monoklonális antitest, amely terápiás lehetőség lehet a TA-TMA kezelésében. Megelőzheti az endothelialis károsodást azáltal, hogy megakadályozza a terminális komplement út aktiválódását és a következményes sejtkárosodás kialakulását [31].

Az eculizumabot elsóként 2014-ben Jodele és mtsai alkalmazták komplementgátló kezelésként őssejt-transzplantáción átesett gyermekekben [32]. Megfigyeléseik alapján TA-TMA esetén nagyobb eculizumabdózisokra van szükség a terápiás eculizumabszint eléréséhez, mint atípusos HUS esetén, és javasolt a szérumszint monitorozása a kellően hatékony kezelés eléréséhez [33].

A TMA szolid szervtranszplantáció után is egy ritka, de súlyos szövődményt jelent. A pontos patomechanizmusa még szintén ismeretlen, kiváltásában az ischaemiásreperfúziós károsodásnak, az immunszuppresszív szereknek és az akut fertőzéseknek is szerepe lehet [34]. Az őssejt-transzplantációhoz társult TMA-hoz hasonlóan, kombinált vese- és hasnyálmirigy-transzplantáción átesett betegnél is alkalmaztak eculizumabot a szekunder TMA kezelésére [35]. Az eculizumab mellett más komplementgátló kezelések, mint a komplementreceptor-2/ faktor H-fúziós protein TT30, a C3 inhibitorok, a Clészteráz-inhibitor és a D-faktor-inhibitorok is ígéretesek lehetnek a TMA kezelésében. Az új terápiás célpontok még fejlesztés alatt állnak, hatékonyságuk és biztonságosságuk felméréséhez további klinikai vizsgálatok szükségesek [36].

A defibrotid egy sertésoligonukleotid, amely lokális gyulladásgátló, antithromboticus és antiischaemiás hatással rendelkezik. TA-TMA esetén az eculizumab mellett fontos kezelési lehetőség lehet, hiszen közvetlenül a komplementaktiváció endothelkárosító hatását előzi meg [29, 37].

\section{Következtetés}

Az elmúlt egy évtizedben a TA-TMA patomechanizmusával kapcsolatos ismereteink jelentősen szélesedtek. Bár a TA-TMA diagnosztikus kritériumrendszerei folyamatosan változnak, a jövőben a komplementparaméterek monitorozása a TTP-hez és HUS-hoz hasonlóan segítheti a klinikusokat a gyors és pontos diagnózisban, a kezelésre szoruló betegek optimális kiválasztásában, a terápia várható hatékonyságának előrejelzésében és a terápia eredményességének monitorizálásában. A terminális komplement út aktivitásának monitorozása nemcsak a TA-TMA diagnosztikus kritériumrendszerét formálhatja át, hanem egyben új terápiás célpontokra mutathat rá a jelentős morbiditással és mortalitással járó őssejt-transzplantációs szövődmény kezelésében. További longitudinális, nagy betegszámú kohorszvizsgálatok szükségesek a TA-TMA aktivitását jelző paraméterek megismerésére, amely lehetővé tenné a betegek hatékony kiválasztását az optimális kezelés biztosításához.
Anyagi támogatás: Az első szerző a Semmelweis Egyetem Doktori Iskolájának nappali tagozatos hallgatójaként a doktori keret segítségével végezte a vizsgálatokat.

Szerzői munkamegosztás: H. O.: A kézirat megírása. P. Z., K. K., K. Cs., S. A., Cs. K., S. J., K. G. H. O., P. Z., K.G.: A vizsgálati koncepció és terv kidolgozása. K. K., K. Cs., S. A., Cs. K., J. K., H. O., K. G.: Betegbevonás, őssejt-transzplantáció végzése, klinikai adatok értékelése. H. O., P. Z., K. G.: Az adatok statisztikai analízise, ábrák, táblázatok összeállítása. H. O., P. Z., K. K., K. Cs., S. A., Cs. K., J. K., K. G.: Kézirat összeállítása, kritikus javítása. A cikk végleges változatát valamennyi szerző elolvasta és jóváhagyta.

Érdekeltségek: A szerzőknek nincsenek érdekeltségeik.

\section{Irodalom}

[1] Furlan M, Robles R, Galbusera M, et al. Von Willebrand factorcleaving protease in thrombotic thrombocytopenic purpura and the hemolytic-uremic syndrome. N Engl J Med. 1998; 339: 1578-1584.

[2] Jodele S, Laskin BL, Dandoy CE, et al. A new paradigm: Diagnosis and management of HSCT-associated thrombotic microangiopathy as multi-system endothelial injury. Blood Rev. 2015; 29: 191-204

[3] Loirat C, Fakhouri F, Ariceta G, et al. An international consensus approach to the management of atypical hemolytic uremic syndrome in children. Pediatr Nephrol. 2016; 31: 15-39.

[4] Moschcowitz E. An acute febrile pleiochromic anemia with hyaline thrombosis of the terminal arterioles and capillaries: an undescribed disease. 1925. Mt Sinai J Med. 2003; 70: 352-355.

[5] Franchini M. Atypical hemolytic uremic syndrome: from diagnosis to treatment. Clin Chem Lab Med. 2015; 53: 1679-1688.

[6] Loirat C, Frémeaux-Bacchi V. Atypical hemolytic uremic syndrome. Orphanet J Rare Dis. 2011; 6: 60.

[7] Campistol JM, Arias M, Ariceta G, et al. An update for atypical haemolytic uraemic syndrome: diagnosis and treatment. A consensus document. Nefrologia 2015; 35: 421-447.

[8] Besbas N, Karpman D, Landau D, et al. A classification of hemolytic uremic syndrome and thrombotic thrombocytopenic purpura and related disorders. Kidney Int. 2006; 70: 423-431.

[9] Sarode R, Bandarenko N, Brecher ME, et al. Thrombotic thrombocytopenic purpura: 2012 American Society for Apheresis (ASFA) consensus conference on classification, diagnosis, management, and future research. J Clin Apher. 2014; 29: 148-167.

[10] Grisaru S. Management of hemolytic-uremic syndrome in children. Int J Nephrol Renovasc Dis. 2014; 7: 231-239.

[11] Obut F, Kasinath V, Abdi R. Post-bone marrow transplant thrombotic microangiopathy. Bone Marrow Transplant. 2016; 51: 891-897.

[12] Jodele S, Dandoy CE, Myers KC, et al. New approaches in the diagnosis, pathophysiology, and treatment of pediatric hematopoietic stem cell transplantation-associated thrombotic microangiopathy. Transfus Apher Sci. 2016; 54: 181-190.

[13] Jodele S, Zhang K, Zou F, et al. The genetic fingerprint of susceptibility for transplant-associated thrombotic microangiopathy. Blood 2016; 127: 989-996.

[14] Uderzo C, Bonanomi S, Busca A, et al. Risk factors and severe outcome in thrombotic microangiopathy after allogeneic hematopoietic stem cell transplantation. Transplantation 2006; 82; 638-644. 
[15] Cho BS, Yahng SA, Lee SE, et al. Validation of recently proposed consensus criteria for thrombotic microangiopathy after allogeneic hematopoietic stem-cell transplantation. Transplantation 2010; 90: 918-926

[16] Laskin BL, Goebel J, Davies SM, et al. Small vessels, big trouble in the kidneys and beyond: hematopoietic stem cell transplantation-associated thrombotic microangiopathy. Blood 2011; 118: 1452-1462.

[17] Ho VT, Cutler C, Carter S, et al. Blood and marrow transplant clinical trials network toxicity committee consensus summary: thrombotic microangiopathy after hematopoietic stem cell transplantation. Biol Blood Marrow Transplant. 2005; 11: 571-575.

[18] Ruutu T, Barosi G, Benjamin RJ, et al. Diagnostic criteria for hematopoietic stem cell transplant-associated microangiopathy: results of a consensus process by an International Working Group. Haematologica 2007; 92: 95-100.

[19] García-Martin P, Alarcón-Payer C, López-Fernández E, et al. Transplantation-associated thrombotic microangiopathy in patients treated with sirolimus and cyclosporine as salvage therapy for graft-versus-host disease. Ann Pharmacother. 2015; 49: 986994.

[20] Jodele S, Davies SM, Lane A, et al. Diagnostic and risk criteria for HSCT-associated thrombotic microangiopathy: a study in children and young adults. Blood 2014; 124: 645-653.

[21] Mannucci PM, Cugno M. The complex differential diagnosis between thrombotic thrombocytopenic purpura and the atypical hemolytic uremic syndrome: Laboratory weapons and their impact on treatment choice and monitoring. Thromb Res. 2015; 136: 851-854.

[22] Jodele S, Licht C, Goebel J, et al. Abnormalities in the alternative pathway of complement in children with hematopoietic stem cell transplant-associated thrombotic microangiopathy. Blood 2013; 122: 2003-2007.

[23] Rosenthal J. Hematopoietic cell transplantation-associated thrombotic microangiopathy: a review of pathophysiology, diagnosis, and treatment. J Blood Med. 2016; 7: 181-186.

[24] Holbro A, Passweg JR. Management of hemolytic anemia following allogeneic stem cell transplantation. Hematology Am Soc Hematol Educ Program 2015; 2015: 378-384.

[25] Didsbury MS, Mackie FE, Kennedy SE. A systematic review of acute kidney injury in pediatric allogeneic hematopoietic stem cell recipients. Pediatr Transplant. 2015; 19: 460-470.

[26] Ganapathi L, Arnold A, Jones S, et al. Use of cidofovir in pediatric patients with adenovirus infection. Version 1. Fl000Res. 2016; 5: 758.

[27] Yamada-Fujiwara M, Miyamura K, Fujiwara T, et al. Diagnosis of intestinal graft-versus-host disease and thrombotic microangi- opathy after allogeneic stem cell transplantation. Tohoku J Exp Med. 2012; 227: 31-37.

[28] El-Bietar J, Warren M, Dandoy C, et al. Histologic features of intestinal thrombotic microangiopathy in pediatric and young adult patients after hematopoietic stem cell transplantation. Biol Blood Marrow Transplant. 2015; 21: 1994-2001.

[29] Kim SS, Patel M, Yum K, et al. Hematopoietic stem cell transplant-associated thrombotic microangiopathy: review of pharmacologic treatment options. Transfusion 2015; 55: 452-458.

[30] Sarode R, McFarland JG, Flomenberg N, et al. Therapeutic plasma exchange does not appear to be effective in the management of thrombotic thrombocytopenic purpura/hemolytic uremic syndrome following bone marrow transplantation. Bone Marrow Transplant. 1995; 16: 271-275.

[31] Legendre CM, Licht C, Muus P, et al. Terminal complement inhibitor eculizumab in atypical hemolytic-uremic syndrome. $\mathrm{N}$ Engl J Med. 2013; 368: 2169-2181.

[32] Jodele S, Fukuda T, Vinks A, et al. Eculizumab therapy in children with severe hematopoietic stem cell transplantation-associated thrombotic microangiopathy. Biol Blood Marrow Transplant. 2014; 20: 518-525.

[33] Jodele S, Fukuda T, Mizuno K, et al. Variable eculizumab clearance requires pharmacodynamic monitoring to optimize therapy for thrombotic microangiopathy after hematopoietic stem cell transplantation. Biol Blood Marrow Transplant. 2016; 22: 307315.

[34] Verbiest A, Pirenne J, Dierickx D. De novo thrombotic microangiopathy after non-renal solid organ transplantation. Blood Rev. 2014; 28: 269-279.

[35] Shochet L, Kanellis J, Simpson I, et al. De novo thrombotic microangiopathy following simultaneous pancreas and kidney transplantation managed with eculizumab. Nephrology 2017; 22(Suppl 1): 23-27.

[36] Gavriilaki E, Sakellari I, Anagnostopoulos A, et al. Transplantassociated thrombotic microangiopathy: opening Pandora's box. Bone Marrow Transplant. 2017 Mar 13. doi: 10.1038/ bmt.2017.39. [Epub ahead of print]

[37] Yeates L, Slatter MA, Bonanomi S, et al. Use of defibrotide to treat transplant-associated thrombotic microangiopathy: a retrospective study of the Paediatric Diseases and Inborn Errors Working Parties of the European Society of Blood and Marrow Transplantation. Bone Marrow Transplant. 2017; 52: 762-764.

(Horváth Orsolya dr., Budapest, Albert Flórián út 5-7. 11/4A, 1097 e-mail: orsolyahorvath.mail@gmail.com)

Az Orvosi Hetilap 2017, 158, 879. oldalán (22. szám) megjelent OH-Kvízre három helyes megfejtés érkezett.

\author{
A beküldők: Dr. Bíró László (Budapest), Dr. Janik Leonárd (Budapest) \\ és Dr. Sósik Ibolya (Budapest).
}

A nyerteseknek szívböl gratulálunk.

A nyereményüket - egy, az Akadémiai Kiadó webáruházában kedvezményes vásárlásra jogosító kupont - e-mailen küldjük el. 